\title{
POLJSKA IZMEĐU ISELJAVANJA I USELJAVANJA, U KONTEKSTU CRKVE
}

\author{
Pawet Makosa*
}

Teološki fakultet

Katoličko sveučilište Ivana Pavla II.

u Lublinu, Poljska

makosa@kul.pl
UDK: 314.15:343.343.62(438)]:272

https://doi.org/ 10.34075/cs.55.3.8

Pregledni znanstveni rad Rad zaprimljen 1/2020.

\section{Sažetak}

Poljsku se ponajprije smatra izvorom migracija, ali posljednjih godina zemlja je postala i mjesto naseljavanja izbjeglica i migranata, koji osobito dolaze iz Istočne Europe. $U$ ovom smo radu najprije pokušali prikazati današnje iseljavanje iz Poljske, a zatim predstaviti priljev stranaca u tu zemlju. Pokazali smo i posljedice iseljavanja za Poljsku. Zatim smo se fokusirali na učenje Crkve o iseljenicima, a posebno na brigu za njihovo duhovno dobro. Drugi dio članka posvećen je useljenicima u Poljsku. Razmišljanje završava predstavljanjem trenutačnih podataka o broju imigranata i razlozima naseljavanja $u$ Poljskoj. Prikazali smo poljsku državnu politiku s tim u vezi te prešli na stav Rimokatoličke Crkve u pogledu prihvaćanja izbjeglica i migranata. Na temelju provedenih analiza ustanovili smo da je politika poljske države otvorena uglavnom prema pridošlicama iz Istočne Europe, dok potencijalnim migrantima sa Srednjeg Istoka i iz Afrike, poljska Vlada nudi pomoć samo u privremenom naseljavanju. S druge strane, Rimokatolička Crkva u Poljskoj naglašava potrebu otvorenosti prema svim ljudima kojima je pomoć potrebna, premda primjećuje da je potrebno educiranje javnosti o tom pitanju. Rješenja prihvaćena u Poljskoj rezultirala su masovnim priljevom migranata iz istočnoeuropskih zemalja, posebno iz Ukrajine.

Ključne riječi: migracije, Poljska, Katolička Crkva, poljska država

Ovaj je rad napisan na temelju podataka dobivenih $\mathrm{u}$ istraživanju koje je financirao Nacionalni znanstveni centar u Poljskoj. Registracijski broj projekta je: 2016/21/B/HS1/00834. 
Poljska se ponajprije smatra izvorom migracija, budući da je njezino iseljeništvo rasuto po cijelom svijetu. No posljednjih je godina ta zemlja ujedno postala i mjesto doseljavanja izbjeglica i migranata, osobito iz Istočne Europe. Cilj ovog rada je razmotriti migrantsku situaciju u Poljskoj u odnosu na učenje Rimokatoličke Crkve. Najprije ćemo govoriti o sadašnjem iseljavanju iz Poljske, a potom o pritjecanju stranaca u zemlju. Prikazat ćemo također i utjecaj iseljeništva na zemlju iseljavanja. Potom će predmet našeg promišljanja biti učenje Crkve o iseljenicima, osobito skrb o njihovu duhovnom blagostanju. Drugi dio rada posvećen je doseljavanju u Poljsku. Razmišljanje ćemo završiti prikazom trenutačnih podataka o broju doseljenika i njihovim razlozima naseljavanja u Poljskoj. Za početak, prikazat ćemo poljsku državnu politiku u vezi s time, a zatim prijeći na stav Rimokatoličke Crkve u pogledu prihvaćanja izbjeglica i migranata.

\section{RAZMJeri i UZROCI iseluavanja iz POLJSKe NAKON 2004.}

Nakon što je Poljska postala članicom Europske unije 2004. godine, Poljaci su mogli legalno raditi u Ujedinjenom Kraljevstvu, Republici Irskoj i Švedskoj. Nakon toga su 1. svibnja 2006. godine Španjolska, Portugal, Finska, Grčka i Island također otvorili takvu mogućnost, a Italija im se pridružila u srpnju iste godine. Ubrzo su se i Nizozemska i Luksemburg (svibanj 2007.) te Francuska (srpanj 2008.) pridružile skupini tih zemalja. Belgija, Danska i Norveška (koja nije članica EU-a) otvorile su svoje tržište rada 1. svibnja 2009. Posljednje zemlje koje su iskoristile cijelo sedmogodišnje prijelazno razdoblje (koje završava 1. svibnja 2011.), bile su Njemačka i Austrija. Njima se pridružila Švicarska, koja nije članica Europske unije, ali s njom ima brojne sporazume ${ }^{1}$.

Na početku svojega članstva u EU-u Poljaci su najčešće emigrirali u zemlje poput Ujedinjenog Kraljevstva, Njemačke, Irske, Italije, Nizozemske, Španjolske, Austrije, Norveške, Švedske i Francuske $^{2}$. Prema podacima iz 2007., kada migracije dosežu vrhunac, u inozemstvu je boravilo 2270000 Poljaka, uključujući 1860000 njih u zemljama Europske unije ${ }^{3}$. Podaci temeljeni na osobnom kontaktu

1 W. Danilewicz, Wybrane cechy i strategie poakcesyjnych migracji z Polski, Warmińsko-Mazurski Kwartalnik Naukowy, Nauki Społeczne, 1 (2012.) 1, str. 37.

2 Centrum Badania Opinii Społecznej, Praca Polaków w krajach UE. Komunikat z badań, CBOS, Warszawa 2006.

3 Główny Urząd Statystyczny. Departament Badań Demograficznych i Rynku Pracy, Informacja o rozmiarach i kierunkach czasowej emigracji z Polski w latach 2004 - 2013, GUS, Warszawa 2014, str. 3. 
svećenika sa stanovnicima svojih župa, posebno tijekom pastoralnih posjeta, pokazali su da je 2014. godine broj Poljaka koji su bili registrirani u svim poljskim župama, ali su zapravo otišli u inozemstvo iznosio gotovo 2,7 milijuna ${ }^{4}$. Stoga se mora zaključiti da su „međunarodne migracije društveno-ekonomski fenomen koji je trajno upisan u suvremenu poljsku povijest". ${ }^{5}$

Poljaci napuštaju svoju domovinu uglavnom iz ekonomskih razloga. Najčešći razlog je njihovo subjektivno uvjerenje da ondje nema perspektive za život (53,8 \%), potom veća zarada i viši životni standard (45,2 \%) koji se očekuju nakon iseljenja. Velik broj Poljaka kao razlog također navodi želju za učenje stranog jezika, učenje o svijetu i stjecanje iskustva (44,2 \%). Za neke (17,7\%) uzrok migracije je slučajnost. Svaki deseti mladi Poljak (9,9\%) govori da se želi obrazovati u inozemstvu ${ }^{6}$.

\section{Posluedice iseluavanja IZ PoLJSKe}

Migracije stanovništva imaju ozbiljne posljedice, ali ne samo one ograničene na osobnu sferu. Njihovi su učinci na obiteljski život vrlo jasni, a zbog velikih razmjera te pojave, očiti su i učinci na čitave zajednice $^{7}$. Zasigurno pozitivan učinak migracije jest prevladavanje nezaposlenosti, uzrok koje je loša gospodarska situacija. Nezaposlenost značajno utječe na nisko samopoštovanje, posebno kod muškaraca ${ }^{8}$. Stoga je zapošljavanje u inozemstvu obično pozitivna kvalitativna promjena za migrante i njihovu obitelj. Učenje stranog jezika ili upoznavanje strane kulture također se može navesti kao pozitivan učinak napuštanja Poljske.

U gospodarskom smislu, onaj koji ima korist od migracije ponajprije je zemlja odredišta, zbog činjenice da migranti popunja-

4 Instytut Statystyki Kościoła Katolickiego, Annuarium Statisticum Ecclesiae in Polonia ad 2015, ISKK, Warszawa 2015, str. 4.

5 Główny Urząd Statystyczny. Departament Badań Demograficznych i Rynku Pracy, Informacja o rozmiarach i kierunkach czasowej emigracji z Polski w latach 2004 - 2013, GUS, Warszawa 2014, str. 1.

6 M. Budnik, Uwagi o współczesnej emigracji Polaków (2004-2008), Przegląd Polsko-Polonijny, 3(2012.) 1, str. 209; R. Bera, Aksjologiczny sens pracy a poczucie jakości życia młodych emigrantów polskich, UMCS, Lublin 2008, str. 103-105.

7 B. Solga, Miejsce i znaczenie migracji zagranicznych w rozwoju regionalnym, Studia Ekonomiczne. Zeszyty Naukowe Uniwersytetu Ekonomicznego w Katowicach, 309 (2017.) 1, str. 158 et seq.

8 Vidi. P. Kaczmarczyk, Współczesne migracje zagraniczne Polaków - skala, struktura oraz potencjalne skutki dla rynku pracy, Polish-American Freedom Foundation, Warszawa 2006, str. 14. 
vaju praznine na ondašnjem tržištu rada, pridonose povećanju BDPa i pomažu u prevladavanju demografske krize koja je poprimila dramatične razmjere u gotovo cijeloj Europi ${ }^{9}$. Dobrobiti za zemlju podrijetla nisu tako očite. $\mathrm{S}$ jedne strane, migranti šalju novac $\mathrm{u}$ zemlju iseljeništva, pomažući tako svojim obiteljima i prijateljima, ili ulažu u namjeri da se vrate u svoju domovinu. Ipak, zemlja podrijetla također bilježi pad broja stanovnika i nedostatak radne snage na lokalnom tržištu. To se posebno odnosi na kvalificirane, pa i iznadprosječno nadarene osobe, jer je opće poznato da se odljev mozgova ${ }^{10}$ događa zbog nuđenja odgovarajućih uvjeta rada u inozemstvu onima koji su talentirani i kvalificirani, zbog kojih oni masovno napuštaju svoju zemlju podrijetla.

Također valja napomenuti da slanje novca obitelji u Poljskoj može imati i negativne posljedice. S jedne strane, povećava se rizik od korištenja droga i stimulansa, a, s druge strane, ljudi koji primaju novac iz inozemstva mogu se odreći svoje profesionalne aktivnosti ili ju ograničiti. Takve situacije dovode do ekonomskih problema u zemlji ili regiji ${ }^{11}$.

Jedan od najznačajnijih problema koje uzrokuje migracija jest takozvano eurosirotište, tj. potpuno ili djelomično napuštanje djece od strane roditelja koji borave u inozemstvu. Razmjeri te pojave u Poljskoj vrlo su veliki; primjerice, 2009. godine bilo je oko 150 000 djece bez roditelja ${ }^{12}$. Ovaj je problem višeslojan, ali nesumnjivo destruktivan za djecu i adolescente koji odrastaju bez roditelja ili sa samo jednim od njih. Stručnjaci tvrde da, ako su roditelji odsutni dulje od 6 mjeseci, djeca, posebno u razdoblju adolescencije, razvijaju problematična ponašanja, kao što su neopravdani izostanci iz škole, korištenje stimulansa, itd. Uočavaju se i mentalni poremećaji, poput anksioznosti i depresije ${ }^{13}$.

9 Usp. M. Kluz, Człowiek w konfrontacji ze współczesną emigracją zarobkową, Studia Sandomierskie, 20 (2013), nr 2, str. 127.

10 Vidi. C. Teney, Introduction, in: Brain Drain - Brain Gain: European Labour Markets in Times of Crisis, A. Schellinger (ur.), Friedrich Ebert Stiftung, Bonn 2015, str. 5 .

11 K. Iglicka, Bilans kosztów i korzyści najnowszej fali migracji zarobkowych z Polski oraz konsekwencje tego odpływu, u: Migracje zagraniczne a polityka rodzinna, J. Szymborski, A. Potrykowska (eds.), RPO, Warszawa 2009, str. 50.

12 Isto, str. 49. Vidi. B. Walczak, Społeczne, edukacyjne i wychowawcze konsekwencje migracji rodziców i opiekunów prawnych uczniów szkół podstawowych, gimnazjalnych i ponadgimnazjalnych, Pedagogium, Warszawa 2008.

13 B. Boćwińska-Kulik, Przeżycia dzieci migrantów - głos z gabinetu psychoterapeutycznego, u: Procesy migracji w społeczeństwie otwartym. Perspektywa edukacji międzykulturowej, J. Nikitorowicz, D. Misiejuk (ur.), Trans Humana, Białystok 2009, str. 351, 358. 
U kontekstu ove tematike treba napomenuti da migracija utječe i na vjerski te moralni život, najčešće na negativan način. Zbog rada nedjeljom, ograničenog pristupa pastoralnoj skrbi na poljskom jeziku, nedostatka društvenih kontakata, migranti zanemaruju prakticiranje vjere svoje vjerske zajednice ${ }^{14}$. Taj je problem uočila Druga poljska plenarna sinoda, koja je migracije opisala kao odvojenost zbog stjecanja zarade, što ima ponižavajući učinak na obitelj ${ }^{15}$. Iseljenici rijetko pribivaju nedjeljnoj misi, a kao glavne razloge navode nepostojanje mjesne katoličke crkve i nepoznavanje jezika. Slabljenje vjere ostavlja posljedice ne samo na pojedinca nego i na obitelj i društvo ${ }^{16}$. Uočava se i pojava moralnih opasnosti, koje uključuju uspostavljanje izvanbračnih veza, zlouporabu alkohola, korištenje droga ili ovisnost o kockanju.

\section{Suvremeno uČEnJe CRKVE O PITANJU POLJSKE EMIGRACIJE}

Crkva u Poljskoj govorila je o emigraciji u više navrata. Druga poljska plenarna sinoda razradila je dokument pod nazivom Poljska pastoralna skrb u inozemstvu, ${ }^{17}$ koji sadrži teološki pogled na fenomen iseljavanja, opis pastoralne skrbi za iseljeništvo, kao i praktične propise i smjernice ${ }^{18}$. Biskupi su naglasili da je Poljska izvor migracija već više od dva stoljeća i definirali su njezine uzroke kao ekonomske, ideološke i političke ${ }^{19}$. Zatim podsjećaju na biblijske osnove gostoprimstva i skrbi za migrante i naglašavaju potrebu pastoralne skrbi na poljskom jeziku uz održavanje poljskih običaja. Istodobno apeliraju na suradnju s lokalnom Crkvom kao i na evangelizaciju lokalnih zajednica. Poljski biskupi također upozoravaju na razdvajanje obitelji, posebno dugotrajno, što vodi razbijanju brakova i obitelji. Također pozivaju da se obrati pozornost na ozbiljne izazove $u$ vezi s odgojem mladih generacija Poljaka ${ }^{20}$.

14 E. Daszkowska, Emigracja Polaków po 2004 roku i jej skutki, Amicus Europae, Warszawa 2014, str. 9.

15 II Polski Synod Plenarny (1991-1999), Pallotinum, Poznań 2001, str. 38.

16 M. Kluz, Człowiek w konfrontacji ze współczesną emigracją zarobkową, Studia Sandomierskie, 20 (2013), nr 2, str. 129.

17 II Polski Synod Plenarny (1991-1999), Pallotinum, Poznań 2001, str. 251-262.

18 Vidi. A. Orczykowski, Problemy emigracji w uchwałach II Polskiego Synodu Plenarnego, Prawo Kanoniczne. Kwartalnik prawno-historyczny, 46 (2003), 1-2, str. 57-89; P. Mąkosa, Geneza i perspektywy duszpasterstwa Polaków w warunkach emigracji, u: Kościól. Komunia i dialog, P. Kantyka, J. Czerkawski, T. Siemieniec (ur.), Jedność, Kielce 2014, str. 399.

19 II Polski Synod Plenarny (1991-1999), Pallotinum, Poznań 2001, str. 243.

20 Isto, str. 246-247. 
Poljska biskupska konferencija, primas Poljske i izaslanik Poljske biskupske konferencije za iseljeništvo razmatrali su pitanje Poljaka $\mathrm{u}$ iseljeništvu u mnogim pismima, apelima i govorima. Pismo poljskih biskupa o pastoralnoj skrbi za iseljeništvo iz 2006., u kojem je upućen apel Poljacima u inozemstvu da sačuvaju „stav kršćanina, katolika i Poljaka, svjesni svog dostojanstva i dužnosti u vjerski ravnodušnim, pa čak i antikršćanskim okruženjima" ${ }^{21}$ samo je jedan primjer. Poljski biskupi ukazali su na velike mogućnosti sudjelovanja u pastoralnom radu na poljskom jeziku i pozvali na međusobnu solidarnost i produbljivanje patriotizma tijekom emigracije.

Još jedan značajan iskaz skrbi za poljske iseljenike su Smjernice Poljske biskupske konferencije o pastoralnoj skrbi za poljske iseljenike $^{22}$, iz 2019. Ovaj je dokument podijeljen u tri dijela: Organizacija pastoralne službe, Ljudi uključeni u pastoralnu službu na poljskom jeziku, Osnovne pastoralne funkcije. U prvom dijelu autori govore o strukturama pastoralne skrbi za poljske iseljenike, posebnu pozornost posvećujući ulozi koordinatora (rektora) pastirā na poljskom jeziku.

U drugom dijelu dokumenta opisana je uloga pojedinih kategorija ljudi uključenih u pastoralnu skrb za useljenike, tj. biskupijskih svećenika, članova instituta posvećenog života i udruga apostolskog života, ali i laika. Posljednji dio smjernica odnosi se na pastoralne funkcije poput službe riječi, sakramentalne i liturgijske službe i službe pastoralne ljubavi. Vrijedi napomenuti da Poljska biskupska konferencija propisuje obvezu provođenja sustavne kateheze za djecu i mlade na svim razinama obrazovanja u poljskim pastoralnim centrima $^{23}$. Također se traži da se priprema za sakramente provodi „u skladu s praksom koja se primjenjuje u Crkvi u Poljskoj”24. Ono što je posebno vidljivo u učenju Crkve o pitanju iseljenih Poljaka jest briga za vjeru i vjerski razvoj iseljenika. Iz tog razloga Crkva koordinira pastoralnu skrb za useljenike gdje god je to potrebno.

\section{TrenutaČNI BROJ DOSELJENIKA U POLJSKU}

Kada je riječ o useljavanju, Poljska je bila utočište mnogim europskim stanovnicima već u 16. stoljeću, posebno tijekom vjerskih ratova nakon reformacije. Kasnije, međutim, nije dolazilo do

21 Konferencja Episkopatu Polski, List o emigracji, KEP, Warszawa 2006.

22 Konferencja Episkopatu Polski, Wytyczne Konferencji Episkopatu Polski dotyczące duszpasterstwa emigracji polskiej, Biblos, Tarnów 2019.

23 Isto, str. 31.

24 Isto, str. 33. 
značajnog useljavanja u Poljsku, zbog njezine teške sudbine. Međutim, već nekoliko godina dolazi do masovnog priljeva Ukrajinaca i, premda u manjoj mjeri, građana iz zemalja poput Bjelorusije, Indije, Gruzije i Vijetnama ${ }^{25}$.

Broj imigranata koji imaju pravo boravka u Poljskoj povećan je sa oko 175000 u 2015. godini na 212000 u 2016. i 266000 u 2017. te na više od 325000 u 2018., a danas se popeo na 382000 njih $^{26}$. Broj registriranih zaposlenika iz Ukrajine povećan je trinaest puta od 2014., a Bjelorusa i Moldavaca šest puta ${ }^{27}$. Neki procjenjuju da je broj ukrajinskih državljana koji trenutačno žive u Poljskoj najmanje 800 000, a ta je skupina još uvijek podložna dinamičnom rastu $^{28}$. Nesumnjivo je da je njihov broj dosegnuo povijesni rekord. Činjenica je da samo u Krakowu više od dvije tisuće ukrajinske djece pohađa osnovne škole. Krakow je bio prvi poljski grad koji je uveo četiri sata tjedno ukrajinskog jezika u odabrane škole ${ }^{29}$. Pritjecanje stranaca na krakovskim sveučilištima još je brže; na nekim područjima (posebno ekonomiji) Ukrajinci bi mogli činiti čak trećinu studenata ${ }^{30}$.

Masovni dolazak doseljenika iz Ukrajine dogodio se nakon 2014. godine, tj. nakon izbijanja oružanog sukoba u istočnoj Ukrajini. Uvođenje novih propisa 2014. godine također nije bilo bez značenja - novi Zakon o strancima ${ }^{31}$ sadrži određena pojednostavnjenja u području legalizacije boravka u Poljskoj, posebno za osobe poljskog podrijetla. Poljska je Ukrajincima izdala više od milijun poljskih iskaznica, što znači da nakon samo godinu dana mogu postati poljski državljani ${ }^{32}$.

25 Urząd do spraw Cudzoziemców, Przyrost liczby cudzoziemców, on-line, https:// udsc.gov.pl/statystyki/raporty-okresowe/raport-roczny-legalizacja-pobytu/2018-2/ (10. 7. 2019).

26 Isto.

27 Z. Bartuś, Ukraińcy zostaną Polakami, on-line, https://dziennikpolski24.pl/ ukraincy-zostana-polakami-ilu-milion-dwa-miliony-wszystko-zalezy-od-sytuacji-na-wschodzie-oraz-polityki-polskiego-rzadu-i/ar/c3-14145441 (10. 7. 2019).

28 M. Jaroszewicz, O. Małynowska, Najnowsza migracja z Ukrainy do Polski: (nie) stały fenomen? Fundacja Batorego, Warszawa 2018, str. 3.

29 Z. Bartuś, Ukraińcy zostaną Polakami, on-line, https://dziennikpolski24.pl/ ukraincy-zostana-polakami-ilu-milion-dwa-miliony-wszystko-zalezy-od-sytuacji-na-wschodzie-oraz-polityki-polskiego-rzadu-i/ar/c3-14145441 (10. 7. 2019).

30 Isto.

31 Ustawa z dnia 12 grudnia 2013 roku o cudzoziemcach, Dz. U. z 2013 roku, poz. 1650.

32 Z. Bartuś, Ukraińcy zostaną Polakami, on-line, https://dziennikpolski24.pl/ ukraincy-zostana-polakami-ilu-milion-dwa-miliony-wszystko-zalezy-od-sytuacji-na-wschodzie-oraz-polityki-polskiego-rzadu-i/ar/c3-14145441 (10. 7. 2019). 
Prema riječima stručnjaka, trenutačni val ukrajinske migracije u Poljsku najvjerojatnije se ne bi dogodio da nije bilo naglog pogoršanja ekonomske situacije i sigurnosti Ukrajinaca, što je rezultat ruske aneksije Krima i izbijanja nerazriješenog sukoba u istočnoj Ukrajini. Glavni razlog povećanog pritjecanja ukrajinskih migranata u Poljsku bilo je značajno povećanje razlike u plaćama između Poljske i Ukrajine, u svjetlu naglog pogoršanja životnog standarda ${ }^{33}$. Uključujući inflaciju, ukrajinski BDP smanjio se za više od $16 \%{ }^{34}$. Sukob u istočnoj Ukrajini doveo je do pojave preusmjeravanja nekih ukrajinskih migranata s ruskoga na poljsko tržište ${ }^{35}$.

Geografski položaj i kulturna bliskost s Ukrajinom, dobro razvijene mreže migracijskih veza i naposljetku određena rješenja na području migracijske politike također su od velike važnosti ${ }^{36}$.

Takozvani sustav deklaracija, pod kojim je dopušteno povjeriti posao strancu bez potrebe za radnom dozvolom, u trajanju ne dužem od šest mjeseci tijekom sljedećih dvanaest mjeseci, ovdje igra posebnu ulogu u privlačenju ukrajinskih državljana. U praksi to znači da su stanovnici Ukrajine uz minimalne formalnosti i financijske troškove mogli ostvariti pravo na legalni kratkoročni rad u Poljskoj ${ }^{37}$.

Razlozi masovnog iseljavanja Ukrajinaca i useljavanja u Poljsku su i niski troškovi putovanja, nepostojanje većih jezičnih prepreka, kao i vrlo široka ukrajinska migracijska mreža u Poljskoj. Jedan od pojmova koji karakterizira ukrajinsku migraciju u Poljsku je izraz „lokalna mobilnost”, koji označava kružnu migraciju do koje dolazi zbog zemljopisne, kulturne i jezične blizine ${ }^{38}$.

Poljska sve više postaje odredišna zemlja za migracije s Istoka iz sljedećih razloga:

1. Poljska je jedna od najdinamičnijih zemalja u razvoju, s velikim ekonomskim potencijalom.

33 M. Jaroszewicz, O. Małynowska, Najnowsza migracja z Ukrainy do Polski: (nie) stały fenomen? Fundacja Batorego, Warszawa 2018, str. 2.

34 Svjetska banka, Ukraine Systematic Country Diagnostic. Towards Sustainable Recovery and Shared Prosperity, World Bank Group, Washington D.C., 2017.

35 M. Jaroszewicz, O. Małynowska, Najnowsza migracja z Ukrainy do Polski: (nie) stały fenomen? Fundacja Batorego, Warszawa 2018, str. 2.

36 A. Górny, P. Kaczmarczyk, M. Szulecka, M. Bitner, M. Okólski, U. Siedlecka, A. Stefańczak, Imigranci w Polsce w kontekście uproszczonej procedury zatrudniania cudzoziemców, Uniwersytet Warszawski, Warszawa 2018, str. 24.

37 M. Jaroszewicz, O. Małynowska, Najnowsza migracja z Ukrainy do Polski: (nie) stały fenomen? Fundacja Batorego, Warszawa 2018, str. 2.

38 Isto, str. 3. 
2. Smanjivanje prepreka za mobilnost, uključujući i ulazak Poljske u schengenski prostor, omogućilo je strancima koji dolaze u našu zemlju na srednjoročni i dugoročni boravak, da se slobodno kreću unutar tog prostora i bave se različitim aktivnostima.

3. S ulaskom u EU privlačnost Poljske za dolazak stranaca znatno se povećala, ne samo kao tranzitne zemlje nego i kao mjesta obrazovanja i zaposlenja te zemlje naseljavanja.

4. Masovno iseljavanje Poljaka nakon pristupanja EU-u pridonijelo je promjenama na poljskom tržištu rada, što je rezultiralo nenamirenom potražnjom radne snage, posebno u zanimanjima koja pripadaju takozvanom sekundarnom sektoru tržišta $\operatorname{rada}^{39}$.

Čak 76,9 \% imigranata koji dolaze u Poljsku izvan Europske unije ima zaposlenje, što je jedna od najviših stopa u Europi ${ }^{40}$. Trenutačno Poljska ima najbrže rastuću populaciju ekonomskih migranata u EU-u, i može se pretpostaviti da će njihov broj i dalje rasti ${ }^{41}$.

\section{POLJSKA DRŽAVNA IMIGRACIJSKA POLITIKA}

Postoji rašireno vjerovanje da poljska država nije povoljna za izbjeglice i migrante, ali to je samo djelomično točno. Prethodna poljska Vlada, u skladu s odlukom Vijeća EU-a od 22. rujna 2015., pristala je primiti ukupno 14369 ljudi, uglavnom iz Grčke i Italije. Sadašnja poljska Vlada odlučila je poštovati obveze svojih prethodnika u tom pogledu, no postavila je uvjete koji se odnose na provjeru migranata, provjeru njihova stvarnog identiteta, te je dodala mogućnost izbora migranata koji će biti primljeni u Poljsku.

Planirano preseljavanje nije se, međutim, dogodilo iz više razloga, uglavnom političkih. Cinjenica je da je početkom 2016. jedna sirijska obitelj (6 osoba) dobila odobrenje za preseljenje, ali je odbila doći u Poljsku ${ }^{42}$.

39 Zespół do spraw migracji, Polityka migracyjna Polski, Departament Analiz i Polityki Migracyjnej MSWiA, Warszawa 2019, str. 6.

40 J. Frączyk, Ściągamy najbardziej pracowitych imigrantów w Europie, on-line https:// www.money.pl/gospodarka/sciagamy-najbardziej-pracowitych-imigrantow-w-europie-co-piaty-na-samozatrudnieniu-6389386907424897a.html (10. 7. 2019).

41 Zespół do spraw migracji, Polityka migracyjna Polski, Departament Analiz i Polityki Migracyjnej MSWiA, Warszawa 2019, str. 6.

42 A. Adamczyk, Polska wobec kryzysu imigracyjnego, in. Polityczne i społeczne aspekty wielokulturowości. Migracje i mniejszości, ed. A. Adamczyk, A. Sakson, C. Trosiak, UAM, Poznań 2016, str. 99. 
Danas se, međutim, poljska država ne slaže s prisilnim preseljavanjem izbjeglica. Već 2015. godine poljski predsjednik Andrzej Duda službeno se nije složio s nametanjem takozvanog sustava kvota pri primanju izbjeglica u države članice. Prema njegovu mišljenju to bi trebale provoditi, u najvećoj mogućoj mjeri, pojedine zemlje članice, a ne da kvote nameću institucije EU-a. Predsjednik je zauzeo stav da izbjegličku krizu treba rješavati „na izvoru”, stvaranjem odgovarajućih uvjeta u izbjegličkim kampovima na Srednjem Istoku i pomaganjem zemljama u ratu. Godine 2016. poljski parlament podržao je ideju da se dovodi i financira humanitarna pomoć u zemljama sukoba i susjednim zemljama ${ }^{43}$. Zato poljska država pomaže ljudima u zemljama u kojima se vode sukobi i ratovi. Primjer je pomoć koja se pruža stanovnicima Alepa u Siriji.

Protivljenje mehanizmu prisilnog preseljenja migranata $u$ države članice EU-a opravdano je s jedne strane zbog zabrinutosti za sigurnost građana, posebno u kontekstu terorističkih napada, ali i zbog nevoljkosti migranata da se nastane u Poljskoj. Stajalište poljske Vlade proizlazi i iz javnog mnijenja. Kao što su pokazali rezultati ispitivanja javnog mnijenja u siječnju 2016., samo je 4 \% Poljaka bilo za prihvaćanje migranata. Daleko više ljudi, $36 \%$, bilo je za prihvaćanje izbjeglica, ali samo na ograničeno razdoblje ${ }^{44}$.

Treba reći da Poljska nije zemlja odredišta za izbjeglice i migrante iz Azije i Afrike, zbog niskih socijalnih davanja i nedostatka migracijskih mreža. Najčešće se žele doseliti u Njemačku, Švedsku ili Veliku Britaniju, gdje mnogi njihovi sunarodnjaci već žive i gdje mogu primati širu socijalnu pomoć, a životni standard je također viši. Poljske vlasti tvrde da bi se, ako bi došlo do prisilnog preseljavanja u Poljsku, migranti smještali u posebne centre i zapravo bi im se oduzela sloboda, što se protivi ljudskim pravima i međunarodnom pravu. Ovo stajalište utemeljeno je u praksi. Naime, zaklada Estera je godine 2015. iz Sirije u Poljsku dovela 150 kršćana, ali vrlo brzo su gotovo svi napustili Poljsku i krenuli prema Njemačkoj ${ }^{45}$. Slične su se situacije događale i s ljudima kojima je pomagala Rimokatolička Crkva. Izbjeglice i migranti sa Srednjeg Istoka ne žele živjeti u Poljskoj i odlučuju se za Njemačku kao zemlju prebivališta. Stoga ih je teško prisiliti da se nastane u ovoj zemlji.

43 Isto, str. 101-102; 105.

44 Isto, str. 108.

45 I. Kacprzak, Syryjczycy nie chcą być uchodźcami w Polsce, on-line, https://www. rp.pl/Uchodzcy/303289891-Syryjczycy-nie-chca-byc-uchodzcami-w-Polsce. html (10. 7. 2019). 
Istodobno, poljska država ima otvorenu migracijsku politiku, ali ona se uglavnom tiče migranata iz Istočne Europe. Ovdje posebno valja spomenuti značajne radnje koje su poduzete za Poljake ili za njihove potomke koji su na kraju Drugoga svjetskog rata bili na teritoriju Sovjetskog Saveza ${ }^{46}$. Demografska struktura Poljske i umirovljenje baby boom generacije uzrokovali su manjak radne snage. Procjenjuje se da će se u razdoblju od 2015. do 2020. raspoloživa radna snaga smanjiti za gotovo 590 tisuća, a taj će se proces dodatno intenzivirati u sljedećim godinama. Do godine 2030. radna snaga će se smanjiti sveukupno za više od 1,5 milijuna ljudi ${ }^{47}$. To je, zajedno s razvojem poljske ekonomije, rezultiralo povijesno niskom stopom nezaposlenosti (5 - $6 \%$ ) i velikom potražnjom za radom migranata. Ukratko, poljsku migracijsku politiku možemo okarakterizirati kao onu koja je usredotočena ponajprije na kratkoročne potrebe tržišta rada ${ }^{48}$.

Također, Poljska kao pogranična država EU-a vrlo pažljivo provjerava one koji prelaze granicu i pokušava suzbiti ilegalnu imigraciju. Pedeset četiri tisuće građana zemalja koje nisu članice EU-a nije dobilo dopuštenje da prijeđe poljsku granicu, koja je ujedno predstavlja i vanjsku granicu EU-a (samo za usporedbu - Francuska ih je odbila 70 tisuća, a Španjolska 230 tisuća) $^{49}$.

\section{UČENJE I DJELOVANJE POLJSKE RIMOKATOLIČKE CRKVE ZA DOBROBIT MIGRANATA}

Rimokatolička Crkva u Poljskoj, koja je dominantna vjerska zajednica, više je puta govorila o pitanjima izbjeglica i migranata i poduzimala konkretne radnje u njihovu korist. Stav Crkve u Poljskoj ne razlikuje se od stava pape Franje, ali jest različit od stava Vlade. Uglavnom, učenje se temelji na stavu Crkve razrađenom 1990-ih, za vrijeme pontifikata poljskog pape Ivana Pavla II. ${ }^{50}$

46 Zespół do spraw migracji, Polityka migracyjna Polski, Departament Analiz i Polityki Migracyjnej MSWiA, Warszawa 2019, str. 7.

47 Isto, str. 3.

48 M. Jaroszewicz, O. Małynowska, Najnowsza migracja z Ukrainy do Polski: (nie) stały fenomen? Fundacja Batorego, Warszawa 2018, str. 2.

49 J. Bereźnicki, Polska odprawia $z$ kwitkiem tysiące imigrantów, ale tylu pozwoleń na pobyt nie wydaje nikt inny w UE, on-line, https://spidersweb.pl/bizblog/ imigracja-polska-ue-ukraincy-pozwolenia-pobyt-prace/ (10. 7. 2019).

50 P. Stachowiak, Kilka uwag o paradoksach polskiego katolicyzmu. Na marginesie narracji Kościoła katolickiego w Polsce o kwestii uchodźczej, u: Polityczne i społeczne aspekty wielokulturowości. Migracje i mniejszości, ur. A. Adamczyk, A. Sakson, C. Trosiak, UAM, Poznań 2016, str. 141. 
Predsjedništvo Poljske biskupske konferencije u svojem je izvješću od 8. rujna 2015. iznijelo svoje mišljenje u tri točke ${ }^{51}$ :

„1. Glavni napor svijeta trebao bi biti usmjeren na gašenje sukoba zbog kojih su ljudi prisiljeni spašavati se bježeći iz vlastite zemlje. Zato je potrebno pomoći onima koji pate zbog ratova u svojim zemljama podrijetla

2. Kad je riječ o konkretnoj pomoći izbjeglicama u Poljskoj, nema sumnje da je glavna inicijativa i odgovornost na plećima svjetovnih vlasti. Oni vode igru. Oni bi u tom pogledu također trebali jamčiti kontrolu, sigurnost i osnovnu dobrobit za izbjeglice.

3. Rimokatolička Crkva u Poljskoj [...] učinit će sve što je u njezinoj moći da olakša izbjeglicama njihovu dramatičnu situaciju. Ne smijemo zaboraviti da smo i mi bili izbjeglice i gosti u stranim zemljama, a na kraju krajeva, svi smo samo ,gosti' na ovoj Zemlji." 52

Kardinal Kazimierz Nycz, nadbiskup Varšave, rekao je da Poljaci ne mogu ostaviti izbjeglice bez pomoći. Prema njegovu mišljenju treba pomoći svima, ali treba oprezno, pametno i pravedno razvijati suradnju triju strana - države, lokalne uprave i nevladinih organizacija ${ }^{53}$.

Predsjedatelj Poljske biskupske konferencije nadbiskup Stanisław Gądecki, pozivajući se na papu Franju, apelirao je na svaku župu da pripremi mjesta za izbjeglice: „Danas je vrijeme da se stvarno iskuša naše kršćanstvo. Potrebno je da se svaka župa koja to može pripremi za prihvat izbjeglica i pomogne im započeti novi život." 54

Vrlo jasan stav o pitanju izbjeglica i migranata sadržan je $u$ priopćenju Vijeća Poljske biskupske konferencije o migracijama, turizmu i hodočašćima. Ono ukazuje na istovjetnost sudbine poljskih izbjeglica i migranata sa sudbinom onih koji danas dolaze $u$ Europu: „Suočavajući se s mržnjom prema strancima, ponekad i prema Poljacima u egzilu, i izuzetno bolnim slikama izbjeglica iz

$51 \quad$ Isto, str. 142.

52 Prezydium Konferencji Episkopatu Polski, Komunikat w sprawie uchodźców, Niedziela, 38 (2015), str. 10.

53 A. Adamczyk, Polska wobec kryzysu imigracyjnego, in. Polityczne i społeczne aspekty wielokulturowości. Migracje i mniejszości, ed. A. Adamczyk, A. Sakson, C. Trosiak, UAM, Poznań 2016, str. 112.

54 S. Gądecki, Dzisiaj nadszedł dla nas czas prawdziwej próby z naszego chrześcijaństwa, on-line, https://www.gloria.tv/article/ VjLm7dHog9DN3LkK2aY8mPyimonferencji (10. 7. 2019). 
Afrike koje traže pomoć na granicama Europe, Kristove riječi o blaženima jasnije se čuju i razumiju, jer: ,Stranac bijah i primiste me'. Sljedeće su riječi također duboke, pune prijetnje: , Odlazite od mene, prokleti [...], jer stranac bijah i ne primiste me'." 55

Vrijedi napomenuti da u citiranim izjavama predstavnika Crkve u Poljskoj nema nikakvog straha od gubitka poljskog kulturnog ili vjerskog identiteta! ${ }^{56}$ Doduše, postoje izjave pojedinih biskupa o tome kako bi bilo „mnogo racionalnije prihvatiti kršćane, jer unatoč svim kulturološkim razlikama imamo zajedničku ontološku osnovu s njima" 57 .

Istodobno treba napomenuti da je glas crkvene hijerarhije koji poziva na prijam izbjeglica i migranata, široko osporavan u poljskom društvu. Zanimljivo je da su to uglavnom tradicionalni katolici ${ }^{58} \mathbf{i}$ kler niže razine uključen u život Crkve $^{59}$.

Biskupi, svjesni takvih stavova svojih vjernika, pokušavaju ih uvjeriti da promijene svoj pristup i izravno govore o potrebi obrazovanja i izgradnje „kulture otvorenosti”. Predsjedatelj Vijeća za migracije, turizam i hodočašće CEP-a rekao je u tom kontekstu: „Možete li se upitati kada prosječni Poljak, posebno iz manjih gradova, može upoznati nekog muslimana ili čak predstavnika bilo koje druge kulture ili religije? Potrebno nam je znanje, i ne smijemo izazivati strahove i teror. Moramo izgraditi kulturu otvorenosti, vođeni mudrošću Evanđelja." 60

Uz pozive da se izbjeglice i migranati prime u Poljsku, biskupi naglašavaju potrebu za uklanjanjem uzroka koji dovode do migracija i izbjeglištva, kao i potrebu za pomaganjem ljudima pogođenim

55 K. Zadarko, Dziś Chrystus ma twarz uchodźcy, on-line, https://www.deon.pl/ religia/wiara-i-spoleczenstwo/art, 1049,dzis-chrystus-ma-twarz-uchodzcy.html (10. 7. 2019).

56 P. Stachowiak, Kilka uwag o paradoksach polskiego katolicyzmu. Na marginesie narracji Kościoła katolickiego w Polsce o kwestii uchodźczej, in: Polityczne i społeczne aspekty wielokulturowości. Migracje i mniejszości, ur. A. Adamczyk, A. Sakson, C. Trosiak, UAM, Poznań 2016, str. 142.

57 H. Hoser, Uchodźcy - wezwanie do nawrócenia, on-line, https://ekai.pl/abp-henryk-hoser-w-rozmowie-z-kai-uchodzcy-wezwanie-do-nawrocenia/ (10. 7. 2019).

58 P. Stachowiak, Kilka uwag o paradoksach polskiego katolicyzmu. Na marginesie narracji Kościoła katolickiego w Polsce o kwestii uchodźczej, u: Polityczne i społeczne aspekty wielokulturowości. Migracje i mniejszości, ur. A. Adamczyk, A. Sakson, C. Trosiak, UAM, Poznań 2016, p. 139.

59 Isto, str. 144.

60 K. Zadarko, Nie zawiedźmy Chrystusa, on-line, https://ekai.pl/nie-zawiedzmy-chrystusa-bp-krzysztof-zadarko-w-rozmowie-z-kai-o-uchodzcach/ (10. 7. 2019). 
ratovima ili katastrofama na mjestima gdje žive ${ }^{61}$. To je vjerojatno upućeno i prema Vladi te mišljenju većeg dijela društva. U praksi se poduzimaju brojne radnje za obnovu bolnica ili škola u Siriji, kao i za pružanje stalne pomoći, npr. medicinske. S crkvene strane uključene su organizacije poput Caritasa i Crkve u potrebi.

\section{ZAKLJUČAK}

U članku je predstavljena trenutačna migracijska situacija u Poljskoj. Zemlja je predstavljena i kao izvor iseljavanja i kao mjesto naseljavanja sve većeg broja imigranata. Prvi dio ovog rada prikazuje razmjere i motive emigriranja iz Poljske, a zatim i posljedice emigriranja za pojedinca i društvo. Predstavili smo i učenje poljske Crkve o migracijama. Drugi dio rada posvećen je pitanju imigracije u Poljsku. Započeli smo predstavljanjem poljske politike prema izbjeglicama i migrantima koji dolaze u Poljsku te prikazali i stav Katoličke Crkve u tom pogledu. Središnji dio rada iznosi sadašnje podatke o imigrantima u Poljskoj i razlozima njihova naseljavanja u ovoj zemlji. Na temelju provedenih analiza utvrdili smo da je politika poljske države otvorena uglavnom prema pridošlicama iz Istočne Europe, dok za migrante sa Srednjeg Istoka i iz Afrike poljska vlada nudi samo pomoć u privremenom naseljavanju potencijalnih migranata. S druge strane, Rimokatolička Crkva u Poljskoj naglašava potrebu otvorenosti prema svim ljudima kojima je pomoć potrebna, premda primjećuje da je neophodno educiranje javnosti o tom pitanju. Rješenja prihvaćena u Poljskoj rezultirala su masovnim priljevom migranata iz istočnoeuropskih zemalja, posebno iz Ukrajine. Primjetan je i znatan priljev radnika iz Bjelorusije, Vijetnama, Indije ili Gruzije. Mnogo je znakova da će se doseljavanje u Poljsku povećati.

61 P. Stachowiak, Kilka uwag o paradoksach polskiego katolicyzmu. Na marginesie narracji Kościoła katolickiego w Polsce o kwestii uchodźczej, in: Polityczne i społeczne aspekty wielokulturowości. Migracje i mniejszości, ur. A. Adamczyk, A. Sakson, C. Trosiak, UAM, Poznań 2016, str. 142. 


\title{
POLAND BETWEEN EMIGRATION AND IMMIGRATION IN AN ECCLESIAL CONTEXT
}

\begin{abstract}
Summary
Poland is associated primarily as a source of migration, but in recent years the country has become a place of settlement for refugees and migrants coming in particular from Eastern Europe. In this paper we first set out to present the current emigration from Poland, then presented the influx of foreigners to the same country. We also presented the consequences of emigration from Poland. Then we concentrated our analysis on the teaching of Church regarding emigrants, and in particular the care for their spiritual good. The second part of the article was devoted to immigration to Poland. The reflection ended with presentation of current data on the number of immigrants and the reasons for settling in Poland. We demonstrated the Polish state policy in this regard, to move on to the position of the Roman Catholic Church as regards the acceptance of refugees and migrants. Based on the analyses conducted we found that the policy of Polish state is open mainly to newcomers from Eastern Europe, while in relation to Middle East and Africa, the Polish government offers only assistance in temporary settlement of potential migrants. In turn, the Roman Catholic Church proclaims the need to be open to all people in need of help, although it notices the need to educate the public in this matter. The solutions adopted in Poland result in a mass influx of migrants from Eastern European countries, especially from Ukraine.
\end{abstract}

Key words: migrations, Poland, Catholic Church, Polish state 